\title{
Comparison of $0.46 \%$ calcium diets with and without added anions with a $0.7 \%$ calcium anionic diet as a means to reduce periparturient hypocalcemia
}

\author{
Jesse P. Goff ${ }^{1}$ and Nicholas J. Koszewski \\ College of Veterinary Medicine, lowa State University, Ames 50011
}

\begin{abstract}
Most studies demonstrating that diets with low dietary cation-anion difference (DCAD) reduce hypocalcemia in cows add enough anions to the diet to reduce urine $\mathrm{pH}$ below 7.0. One objective of these experiments was to determine whether there is any benefit to periparturient plasma Ca concentration if diet anion addition results in a lesser degree of acidification of the cow and urine $\mathrm{pH}$ does not go below 7.0. Another method for reducing hypocalcemia involves feeding a prepartal diet that is Ca deficient. This places the cow in negative Ca balance before calving, stimulating parathyroid hormone (PTH) and 1,25-dihydroxyvitamin D secretion before calving and thus promoting Ca homeostasis at calving. As practiced in the field, low-Ca diets are often about $0.5 \% \mathrm{Ca}$. Our second objective was to determine whether a $0.46 \%$ Ca diet would be sufficiently low in Ca to stimulate PTH secretion before calving. A meta-analysis of the literature suggests that a $0.5 \%$ $\mathrm{Ca}$, low-DCAD diet will reduce hypocalcemia better than a $0.7 \%$ Ca diet. A third objective was to compare periparturient plasma $\mathrm{Ca}$ in cows fed 0.46 or $0.72 \%$ Ca diets with similar DCAD. In experiment 1, anions (primarily chloride) or anions plus Ca were added to a $1.4 \% \mathrm{~K}$ basal diet to create the following diets: $0.46 \%$ $\mathrm{Ca}$ and $+167 \mathrm{mEq} / \mathrm{kg}$ of DCAD, $0.46 \% \mathrm{Ca}$ and -13 $\mathrm{mEq} / \mathrm{kg}$ of DCAD, and $0.72 \% \mathrm{Ca}$ and $-17 \mathrm{mEq} / \mathrm{kg}$ of DCAD. In experiment 2, the same amounts of anion were added to a $2.05 \% \mathrm{~K}$ basal diet to create the following diets: $0.46 \% \mathrm{Ca}$ and $+327 \mathrm{mEq} / \mathrm{kg}$ of DCAD, $0.46 \% \mathrm{Ca}$ and $+146 \mathrm{mEq} / \mathrm{kg}$ of DCAD, and $0.72 \% \mathrm{Ca}$ and $+140 \mathrm{mEq} / \mathrm{kg}$ of DCAD. In experiment 1 , cows fed the diet with $0.46 \% \mathrm{Ca}$ and $+167 \mathrm{mEq} / \mathrm{kg}$ of DCAD had significantly lower plasma Ca concentration after calving than cows fed the 0.46 or $0.72 \%$ Ca diets with anions. Periparturient plasma $\mathrm{Ca}$ concentrations did not differ in cows fed the low-DCAD diets with 0.46 or
\end{abstract}

Received September 13, 2017

Accepted February 1, 2018.

${ }^{1}$ Corresponding author: jpgoff@iastate.edu
$0.72 \%$ Ca. Urine $\mathrm{pH}$ was reduced from 8.27 in the diet with $0.46 \% \mathrm{Ca}$ and $+167 \mathrm{mEq} / \mathrm{kg}$ of DCAD to 7.07 and 7.41 in the 0.46 and $0.72 \% \mathrm{Ca}$ anion diets, respectively. Precalving plasma PTH and 1,25-dihydroxyvitamin D concentrations were similar in cows fed the $0.46 \% \mathrm{Ca}$ diets and the $0.72 \%$ Ca diets, suggesting that the $0.46 \%$ $\mathrm{Ca}$ diets were not low enough in $\mathrm{Ca}$ to place the cow in negative $\mathrm{Ca}$ balance before calving. In experiment 2 , adding the anion supplements to a $2.05 \% \mathrm{~K}$ diet did not reduce urine $\mathrm{pH}$ below 8.0. Periparturient plasma Ca concentrations did not differ in cows in any group in experiment 2. Precalving diets that are $0.46 \% \mathrm{Ca}$ fed ad libitum are too high in Ca to stimulate Ca homeostasis before calving. Adding anions to a diet can benefit periparturient cow plasma $\mathrm{Ca}$ concentration, but only if it alters acid-base status enough to reduce urine $\mathrm{pH}$ below 7.5 .

Key words: hypocalcemia, anion, dietary cation-anion difference, milk fever

\section{INTRODUCTION}

Ender et al. (1971) elegantly demonstrated that adding anions to the precalving diet of cows to reduce DCAD, which they defined as $(\mathrm{mEq}$ of $\mathrm{Na}+\mathrm{mEq}$ of $\mathrm{K})-(\mathrm{mEq}$ of $\mathrm{Cl}+\mathrm{mEq}$ of $\mathrm{S})$ in the diet, improved $\mathrm{Ca}$ status and effectively prevented milk fever. Numerous studies (Block, 1984; Oetzel et al., 1988; Gaynor et al., 1989) have corroborated and refined those observations. Cows fed high-DCAD prepartum diets are in a state of compensated metabolic alkalosis. This reduces the sensitivity of target tissues such as bone and kidney to parathyroid hormone (PTH), compromising Ca homeostasis (Goff et al., 2014). Adding sufficient anions creates a lower DCAD diet and induces a compensated metabolic acidosis in the cow, improving tissue sensitivity to PTH. This restores the competency of Ca homeostatic mechanisms and facilitates a rapid return to normocalcemia after blood Ca concentration decreases at the onset of lactation. However, several practical questions remain about the best practices to use when adding anions to diets to prevent hypocalcemia. 
One question revolves around the proper level of Ca to include in the diet of the cow fed anions. Many studies using anions fed before parturition to reduce milk fever incidence used $\mathrm{Ca}$ chloride and $\mathrm{Ca}$ sulfate as sources of anions (Dishington, 1975; Block, 1984; Oetzel et al., 1988; Beede et al., 1991). Meta-analyses of factors associated with hypocalcemia at calving suggest that the highest incidence of milk fever occurs when diet $\mathrm{Ca}$ is 0.8 to $1.3 \%$ Ca (Oetzel, 1991; Lean et al., 2006). The Lean et al. (2006) model suggests that milk fever incidence should increase from 1 to $2 \%$ of cows when diet $\mathrm{Ca}$ increases from 0.5 to $0.7 \%$. Interestingly, many of the early successful anionic diet studies used diets that were between 0.75 and 1.3\% Ca (Dishington, 1975; Oetzel et al., 1988; Gaynor et al., 1989). One of the objectives of these studies was to test the hypothesis that a $0.7 \% \mathrm{Ca}$ anionic diet would not reduce hypocalcemia at calving as well as a $0.5 \% \mathrm{Ca}$ anionic diet.

Another strategy for reducing periparturient hypocalcemia involves limiting diet $\mathrm{Ca}$ (or diet Ca availability) to levels that place the cow in negative $\mathrm{Ca}$ balance for 7 to $14 \mathrm{~d}$ before calving. Negative Ca balance stimulates the parathyroid gland to secrete PTH within 3 to $4 \mathrm{~d}$ of the diet $\mathrm{Ca}$ reduction, and it remains elevated until calving (Goings et al., 1974). This prolonged exposure to high levels of PTH is able to overcome the tissue resistance to PTH caused by metabolic alkalosis (Goff et al., 1986). This initiates Ca conservation and Ca mobilization mechanisms, such as renal production of 1,25-dihydroxyvitamin $\mathrm{D}\left[\mathbf{1 , 2 5}-(\mathbf{O H})_{2} \mathbf{D}\right]$ and bone resorption, before the onset of lactation (Boda and Cole, 1954; Goings et al., 1974; Green et al., 1981). Prolonged PTH exposure causes osteoclast numbers to increase in the bone before calving even when the cow is in metabolic alkalosis. Recruitment of osteoclasts is a process that can take several days of exposure to elevated PTH (Goff et al., 1986; Liesegang et al., 1998). The cow's homeostasis mechanisms are primed by the low-Ca diet and ready to respond to the $\mathrm{Ca}$ demands of lactation. There is some debate in the field about the diet $\mathrm{Ca}$ concentration that constitutes a low-Ca diet.

Utilizing NRC (2001) calculations, a 600-kg dry cow in late gestation can meet maintenance and fetal requirements for $\mathrm{Ca}$ by absorbing $17 \mathrm{~g}$ of $\mathrm{Ca}$ from her diet each day. The availability of $\mathrm{Ca}$ in forages may be as low as $30 \%$. To meet this cow's requirements, the diet would have to contain at least $57 \mathrm{~g}$ of $\mathrm{Ca}$ if forage supplied all the Ca. This same cow is estimated to consume about $14 \mathrm{~kg} / \mathrm{d}$ of DM in the weeks before calving. Distributing $57 \mathrm{~g}$ of Ca across $14 \mathrm{~kg}$ of DM indicates that a diet can be as low as $0.41 \% \mathrm{Ca}$-all from forage - and still meet the Ca requirement of the animal. The original studies in which milk fever was prevented using the low-Ca precalving diet strategy had total diet Ca below 18 g/d (Boda and Cole, 1954; Goings et al., 1974; Green et al., 1981; Kichura et al., 1982) and likely supplied just 5 to $10 \mathrm{~g}$ of absorbable Ca each day (NRC, 2001). It is difficult to feed prepartum diets that are this low in Ca using typical forages used in the United States, and when cows in the United States are fed ad libitum, their DMI will often ensure that their Ca requirements in late gestation are met or exceeded. Yet diets with more than $0.41 \%$ Ca continue to be promoted by some nutritionists as a low-Ca diet approach to milk fever prevention. Perhaps the NRC (2001) calculations are inaccurate. One objective of these studies was to test the hypothesis that a diet that was about $0.46 \%$ Ca could effectively stimulate PTH and $1,25-(\mathrm{OH})_{2} \mathrm{D}$ production before calving and reduce hypocalcemia.

Another practical question revolves around the degree of acidification needed to reduce the degree of hypocalcemia experienced by a cow. Urine $\mathrm{pH}$ generally reflects blood $\mathrm{pH}$ status and has been used to assess the acidifying activity of the anion diet being fed. Most of the published studies have had an anion-supplemented group of cows with urine pH below 7.0 and usually closer to 6.0 (Jardon, 1995; Charbonneau et al., 2006). The periparturient Ca status of those cows was typically contrasted with that of a control "no anion" group. Control cows were generally in a state of metabolic alkalosis, with urine $\mathrm{pH} \geq 8.0$. Another objective of these studies was to determine whether anion addition improves periparturient plasma Ca concentration, even if there is no or only partial acidification of the cow.

\section{MATERIALS AND METHODS}

All procedures used on the cows in this study were approved by the Iowa State University (Ames) Institutional Animal Care and Use Committee.

\section{Experiment 1}

Sixty Holstein cows from the Iowa State University dairy herd entering their second or greater lactation were enrolled in this study to test the hypothesis that a $0.46 \%$ Ca diet would stimulate Ca homeostatic mechanisms before calving. It also tested the hypothesis that anion supplementation will still benefit periparturient Ca status even if urine $\mathrm{pH}$ remains above recommended levels of 6.5 or less (Goff, 2014). Twenty cows were sequentially assigned to each of 3 treatments: $0.46 \%$ $\mathrm{Ca}$ and $+167 \mathrm{mEq} / \mathrm{kg}$ of DCAD (LC), $0.46 \% \mathrm{Ca}$ and $-13 \mathrm{mEq} / \mathrm{kg}$ of DCAD $(\mathbf{L C}+\mathbf{A})$, or $0.72 \% \mathrm{Ca}$ and $-17 \mathrm{mEq} / \mathrm{kg}$ of DCAD $(\mathbf{H C}+\mathbf{A})$. Cows were assigned 
based on lactation number (a cow was classified as either entering her second lactation or entering her third or greater lactation) and expected date of calving as a completely randomized design experiment. Cows calved between May 15 and September 3, 2010. The study was designed to have the power to detect a $0.5 \mathrm{mg} /$ $\mathrm{dL}$ difference in blood $\mathrm{Ca}$ at calving across the groups. Based on previous studies we have done, we assumed a standard deviation of blood $\mathrm{Ca}$ of $0.8 \mathrm{mg} / \mathrm{dL}$ in cows around the time of calving. With 20 cows expected to be in each treatment and using an $\alpha$ error level of $5 \%$, our statistical power to see this difference in plasma $\mathrm{Ca}$ was $87 \%$. The cows were fed a wheat straw- and corn silage-based diet as described in Table 1. They were acclimated to being fed behind Calan gates (American Calan, Northwood, NH) beginning 4 to 5 wk before expected calving date. At 4 wk before expected calving date, cows began to receive their individual diets. At approximately $1100 \mathrm{~h}$ each day, $15.2 \mathrm{~kg}$ of DM of the basal diet produced in a mixer wagon was placed in a small tub and then $1 \mathrm{~kg}$ of DM of treatment supplement was added. Treatment supplements were prepared ahead of the experiment in large batches. The LC supplement consisted of dried distillers grains without solubles, rice hulls, and $\mathrm{Mg}$ oxide. The $\mathrm{LC}+\mathrm{A}$ supplement had the same carrier, and hydrochloric acid was added as the primary source of chloride anions (Pasturchlor, Landus Cooperative, Ames, IA). The $\mathrm{HC}+\mathrm{A}$ supplement also used hydrochloric acid as in the $\mathrm{LC}+\mathrm{A}$ supplement but substituted Ca carbonate in place of a portion of the $\mathrm{MgO}$ (SoyChlor, Landus Cooperative). The 1-kg treatment supplements were thoroughly mixed into the $15.2-\mathrm{kg}$ basal diet by hand using a silage fork in a $2 \mathrm{~m}$ $\times 25 \mathrm{~cm}$ round plastic swimming pool and then placed into the tub in front of the Calan gate. Hoods on the front of the bins reduced the ability of cows to toss diet out of the bin. Thus, $16.2 \mathrm{~kg}$ of DM of diet was offered to each cow each day, and refusals were weighed back daily on each cow. None of the cows consumed all $16.2 \mathrm{~kg}$ of the DM offered. The composition of each treatment supplement was determined by wet chemistry at the start of the experiment. Forages comprising the basal mix were sampled at the start, middle, and end of each experiment, and the average value of direct nutrient analysis performed by a commercial laboratory (Dairyland Labs, Arcadia, WI) was used in calculating basal diet compositions. Manufacturer-supplied analyses of the nutrient compositions for the protein and anion sources were used to calculate composition of complete TMR diets (Table 1). Briefly, samples sent to the laboratory were wet ashed in $50 \%$ nitric acid using a microwave to speed digestion. The cation mineral concentration was determined by inductively coupled plasma spectrometry. Sulfur was determined by inductively coupled plasma optical emissions spectrometry. Chloride content was determined using a chloridometer (Corning 926 chloride analyzer, Corning, NY). Urine was collected once per week before calving by manual stimulation of the vulva to elicit micturition and allowing at least $100 \mathrm{~mL}$ of urine to be voided before making the collection. The urine $\mathrm{pH}$ was measured on a laboratory $\mathrm{pH}$ meter (Orion Star, A111, Fisher Scientific, Pittsburgh, PA) calibrated before each use. The urine $\mathrm{pH}$ observed during the week before calving was used to determine average urine $\mathrm{pH}$ in each treatment group. Body condition score (5-point scale; Ferguson et al., 1994) was recorded once at 1 to $2 \mathrm{wk}$ precalving. Twice weekly before calving, blood samples were obtained from the jugular vein of each cow using 6 -mL heparinized evacuated tubes via a 1.5 -inch $(3.8$ cm) 20-G needle beginning $3 \mathrm{wk}$ before expected date of calving. Blood samples were also taken at 0 (within $6 \mathrm{~h}$ after calving), $1(24+3 \mathrm{~h}), 4$, and $10 \mathrm{~d}$ after calving from all cows. Blood was subjected to centrifugation at $1,500 \times g$ for $15 \mathrm{~min}$ within $30 \mathrm{~min}$ of collection. Plasma was harvested and stored in cryovials (Nunc, Thermo Scientific, Waltham, MA) at $-20^{\circ} \mathrm{C}$ until it could be analyzed.

\section{Experiment 2}

The second experiment was essentially the same as experiment 1 except that $225 \mathrm{~g}$ of potassium carbonate $\left(\mathrm{K}_{2} \mathrm{CO}_{3}\right.$; K-Plus, Church and Dwight, Trenton, NJ) was added to each diet in addition to the treatment supplements used in experiment 1 (Table 2). Thirtynine Holstein cows from the Iowa State University dairy herd entering their second or greater lactation were sequentially enrolled in this study based on expected calving date and lactation number as a completely randomized design experiment to test the hypothesis that a diet with $0.46 \% \mathrm{Ca}$ and $2.0 \% \mathrm{~K}$ would stimulate $\mathrm{Ca}$ homeostatic mechanisms before calving. It also tested the hypothesis that anion supplementation will still benefit periparturient Ca status even if urine $\mathrm{pH}$ remains above recommended levels of 6.5 or less. Cows used in this study calved between June 4 and October 18, 2011. Thirteen cows were assigned to each of the 3 treatment supplements based on lactation number (entering second or entering third or greater lactation) and expected date of calving: $0.46 \% \mathrm{Ca}$ and $+327 \mathrm{mEq} / \mathrm{kg}$ of DCAD (high-K LC), $0.46 \% \mathrm{Ca}$ and $+141 \mathrm{mEq} / \mathrm{kg}$ of DCAD (high-K LC+A), or $0.72 \% \mathrm{Ca}$ and $+140 \mathrm{mEq} /$ $\mathrm{kg}$ of DCAD (high-K HC+A). The study was designed to have the power to detect a $0.5 \mathrm{mg} / \mathrm{dL}$ difference in blood $\mathrm{Ca}$ at calving across the groups. We assumed a 
standard deviation of blood $\mathrm{Ca}$ of $0.8 \mathrm{mg} / \mathrm{dL}$ in cows around the time of calving. With 13 cows expected to be in each treatment and using an $\alpha$ error level of $5 \%$, our statistical power to see this difference in plasma $\mathrm{Ca}$ was $73 \%$.

The amount of treatment supplement was increased to $1.2 \mathrm{~kg}$ of $\mathrm{DM} / \mathrm{d}$ and the total amount of diet placed into each Calan gate bin was increased to $17 \mathrm{~kg}$ of $\mathrm{DM} / \mathrm{d}$ to ensure that enough diet was offered to allow ad libitum intake. Feed refusals were recorded daily. This experiment also had additional blood samples obtained from each cow at $0.5 \mathrm{~d}$ ( $12 \pm 4 \mathrm{~h}$ after calving) and $48 \pm 7 \mathrm{~h}$ after calving to better define the degree of hypocalcemia and duration of hypocalcemia that might be observed across the dietary treatments.

\section{Blood Analyses}

Precalving blood samples obtained $18 \pm 4$ and $7 \pm 3$ $\mathrm{d}$ before calving (experiment 1 ) and $21 \pm 4,14 \pm 3$, and $7 \pm 3 \mathrm{~d}$ before calving (experiment 2 ) and all samples taken after calving were analyzed for $\mathrm{Ca}(\mathrm{Ca}-$ arsenazio III complex formation, Pointe Scientific, Canton, MI) and $\mathrm{Mg}$ (formation of complex with xylidyl blue, Pointe Scientific) in duplicate. Parathyroid hormone and plasma $1,25-(\mathrm{OH})_{2} \mathrm{D}$ concentrations were determined on a single plasma sample obtained from each cow during the period between 10 and $4 \mathrm{~d}$ before calving, a time point when all cows had been on their respective diets for at least $7 \mathrm{~d}$. The sample was also obtained far enough in advance of calving that plasma Ca concentrations were

Table 1. Composition of the diets fed to cows for the final $4 \mathrm{wk}$ of gestation in experiment 1

\begin{tabular}{|c|c|c|c|}
\hline \multirow[b]{2}{*}{ Item } & \multicolumn{3}{|c|}{ Treatment $^{1}$} \\
\hline & $\mathrm{LC}$ & $\mathrm{LC}+\mathrm{A}$ & $\mathrm{HC}+\mathrm{A}$ \\
\hline \multicolumn{4}{|l|}{ Ingredient, $\%$ of DM } \\
\hline Corn silage & 44.32 & 44.32 & 44.32 \\
\hline Wheat straw & 24.08 & 24.08 & 24.08 \\
\hline Expellers soymeal $^{2}$ & 7.73 & 7.73 & 7.73 \\
\hline Alfalfa-grass hay & 16.74 & 16.74 & 16.74 \\
\hline $\mathrm{K}_{2} \mathrm{SO}_{4}, \mathrm{MgSO}_{4}{ }^{3}$ & 0.22 & 0.22 & 0.22 \\
\hline Salt & 0.12 & 0.12 & 0.12 \\
\hline Vitamin ADE-mineral ${ }^{4}$ & 0.62 & 0.62 & 0.62 \\
\hline Low $\mathrm{Ca}-$ no anion $\mathrm{mix}^{5}$ & 6.17 & 0 & 0 \\
\hline Low $\mathrm{Ca}-$ anion $\operatorname{mix}^{6}$ & 0 & 6.17 & 0 \\
\hline High Ca-anion $\operatorname{mix}^{7}$ & 0 & 0 & 6.17 \\
\hline \multicolumn{4}{|l|}{ Nutrient, \% of DM } \\
\hline $\mathrm{CP}$ & 12.4 & 12.4 & 12.1 \\
\hline NDF (forage NDF) & $47.4(44.1)$ & $47.4(44.1)$ & $47.0(44.1)$ \\
\hline $\mathrm{ADF}$ & 32.4 & 32.4 & 32.9 \\
\hline $\mathrm{NFC}$ & 33.3 & 33.3 & 32.9 \\
\hline Crude fat & 3.1 & 3.1 & 3.0 \\
\hline $\mathrm{NE}_{\mathrm{L}}, \mathrm{Mcal} / \mathrm{kg}$ & 1.45 & 1.45 & 1.43 \\
\hline $\mathrm{Ca}$ & 0.46 & 0.46 & 0.72 \\
\hline $\mathrm{Mg}$ & 0.58 & 0.58 & 0.44 \\
\hline $\mathrm{P}$ & 0.25 & 0.25 & 0.24 \\
\hline K & 1.45 & 1.45 & 1.44 \\
\hline $\mathrm{Cl}$ & 0.44 & 1.08 & 1.10 \\
\hline $\mathrm{Na}$ & 0.12 & 0.12 & 0.12 \\
\hline $\mathrm{S}$ & 0.21 & 0.21 & 0.20 \\
\hline $\mathrm{DCAD}^{8}{ }^{8} \mathrm{mEq} / \mathrm{kg}$ & +167 & -13 & -17 \\
\hline $\mathrm{MP},{ }^{9} \mathrm{~g} / \mathrm{d}$ & 1,195 & 1,181 & 1,165 \\
\hline Absorbable $\mathrm{Ca},{ }^{10} \mathrm{~g} / \mathrm{d}$ & 26 & 26 & 46 \\
\hline \multicolumn{4}{|c|}{$\begin{array}{l}{ }^{1} \mathrm{LC}=0.46 \% \mathrm{Ca} \text { and }+167 \mathrm{mEq} / \mathrm{kg} \text { of } \mathrm{DCAD} ; \mathrm{LC}+\mathrm{A}=0.46 \% \mathrm{Ca} \text { and }-13 \mathrm{mEq} / \mathrm{kg} \text { of } \mathrm{DCAD} ; \mathrm{HC}+\mathrm{A}= \\
0.72 \% \mathrm{Ca} \text { and }-17 \mathrm{mEq} / \mathrm{kg} \text { of DCAD. }\end{array}$} \\
\hline \multicolumn{4}{|c|}{${ }^{2}$ SoyPlus (Landus Cooperative, Ralston, IA). } \\
\hline \multicolumn{4}{|c|}{${ }^{3}$ Dynamate (Mosaic, Lithia, FL). } \\
\hline \multicolumn{4}{|c|}{$\begin{array}{l}{ }^{4} \text { Supplied } 110,000 \mathrm{IU} \text { of vitamin A, } 35,000 \mathrm{IU} \text { of vitamin D, and 2,500 IU of vitamin E/d and met or exceeded } \\
\text { NRC (2001) requirements for trace minerals. }\end{array}$} \\
\hline \multicolumn{4}{|c|}{${ }^{5}$ Dried distillers grains without solubles, rice hulls, and $\mathrm{Mg}$ oxide (Landus Cooperative). } \\
\hline \multicolumn{4}{|c|}{${ }^{6}$ Pasturchlor (Landus Cooperative). } \\
\hline \multicolumn{4}{|c|}{${ }^{7}$ SoyChlor (Landus Cooperative). } \\
\hline \multicolumn{4}{|c|}{${ }^{8} \mathrm{DCAD}=(\mathrm{mEq}$ of $\mathrm{Na}+\mathrm{mEq}$ of $\mathrm{K})-(\mathrm{mEq}$ of $\mathrm{Cl}+\mathrm{mEq}$ of $\mathrm{S})}$. \\
\hline \multicolumn{4}{|c|}{${ }^{9}$ Calculated MP based on $13.4 \mathrm{~kg}$ of $\mathrm{DMI} / \mathrm{d}(\mathrm{NRC}, 2001)$} \\
\hline${ }^{10}$ Calculated absorbable $\mathrm{C}$ & $4 \mathrm{~kg}$ of $\mathrm{DM} / \mathrm{d}($ & & \\
\hline
\end{tabular}


all above $8.6 \mathrm{mg} / \mathrm{dL}$ in those samples. In experiment 1 , the average time before calving for these samples was $7.3 \mathrm{~d}$ before calving for the LC cows (median: $7 \mathrm{~d}$ ), 7.4 $\mathrm{d}$ before calving for the $\mathrm{LC}+\mathrm{A}$ cows (median: $8 \mathrm{~d}$ ), and $7.4 \mathrm{~d}$ before calving for the $\mathrm{HC}+\mathrm{A}$ cows (median: $8 \mathrm{~d}$ ). In experiment 2 , the average time before calving for these samples was $6.5 \mathrm{~d}$ before calving for the high-K LC cows (median: $6 \mathrm{~d}$ ), $6.8 \mathrm{~d}$ before calving for the high-K LC+A cows (median: $6 \mathrm{~d}$ ), and $6.9 \mathrm{~d}$ before calving for the high-K HC+A cows (median: $7 \mathrm{~d}$ ). The PTH was determined in singlicate using an ELISA assay (human PTH ELISA, no. 60-3100, Immutopics, San Clemente, CA). All samples were assayed in the same ELISA plate to eliminate interassay variation. Intra-assay variation of human plasma as reported by the manufacturer is less than 3\%. A plasma sample taken from a cow with milk fever was previously used to validate that the assay was suitable for cows before assay of the samples from this study. The milk fever cow plasma sample was serially diluted and assayed, and the results paralleled the standard curve using the PTH standards supplied with the assay kit. Plasma $1,25-(\mathrm{OH})_{2} \mathrm{D}$ concentration was determined using an enzyme immunoassay (EIA) intended for human plasma samples (1,25-dihydroxvitamin D EIA, Immunodiagnostic Systems, Boldon, UK). This assay uses an antibody column to extract

Table 2. Composition of the high-K diets, with added potassium carbonate, fed to cows for the final 4 wk of gestation in experiment 2

\begin{tabular}{|c|c|c|c|}
\hline \multirow[b]{2}{*}{ Item } & \multicolumn{3}{|c|}{ Treatment $^{1}$} \\
\hline & $\mathrm{LC}$ & $\mathrm{LC}+\mathrm{A}$ & $\mathrm{HC}+\mathrm{A}$ \\
\hline \multicolumn{4}{|l|}{ Ingredient, \% of DM } \\
\hline Corn silage & 52.96 & 52.96 & 52.96 \\
\hline Wheat straw & 7.51 & 7.51 & 7.51 \\
\hline Expeller's soymeal $^{2}$ & 9.40 & 9.40 & 9.40 \\
\hline Grass-alfalfa hay & 21.25 & 21.25 & 21.25 \\
\hline $\mathrm{K}_{2} \mathrm{SO}_{4}, \mathrm{MgSO}_{4}{ }^{3}$ & 0.21 & 0.21 & 0.21 \\
\hline Salt & 0.12 & 0.12 & 0.12 \\
\hline Vitamin ADE-mineral $^{4}$ & 0.76 & 0.76 & 0.76 \\
\hline Low $\mathrm{Ca}-$ no anion $\mathrm{mix}^{5}$ & 6.47 & 0 & 0 \\
\hline Low Ca-anion $\operatorname{mix}^{6}$ & 0 & 6.47 & 0 \\
\hline High Ca-anion mix ${ }^{7}$ & 0 & 0 & 6.47 \\
\hline $\mathrm{K}_{2} \mathrm{CO}_{3}^{8}$ & 1.32 & 1.32 & 1.32 \\
\hline \multicolumn{4}{|l|}{ Nutrient, \% of DM } \\
\hline $\mathrm{CP}$ & 13.0 & 12.9 & 12.7 \\
\hline NDF (forage NDF) & $42.4(38.8)$ & $42.2(38.6)$ & $42.0(38.8)$ \\
\hline $\mathrm{ADF}$ & 28.2 & 28.1 & 28.7 \\
\hline $\mathrm{NFC}$ & 37.0 & 36.8 & 36.6 \\
\hline Crude fat & 3.3 & 3.3 & 3.2 \\
\hline $\mathrm{NE}_{\mathrm{L}}, \mathrm{Mcal} / \mathrm{kg}$ & 1.52 & 1.50 & 1.50 \\
\hline $\mathrm{Ca}$ & 0.46 & 0.46 & 0.72 \\
\hline $\mathrm{Mg}$ & 0.59 & 0.58 & 0.44 \\
\hline $\mathrm{P}^{\circ}$ & 0.27 & 0.27 & 0.26 \\
\hline $\mathrm{K}$ & 2.08 & 2.07 & 2.07 \\
\hline $\mathrm{Cl}$ & 0.40 & 1.04 & 1.06 \\
\hline $\mathrm{Na}$ & 0.09 & 0.09 & 0.09 \\
\hline $\mathrm{S}$ & 0.21 & 0.21 & 0.21 \\
\hline $\mathrm{DCAD},{ }^{9} \mathrm{mEq} / \mathrm{kg}$ & +327 & +146 & +140 \\
\hline $\mathrm{MP},{ }^{10} \mathrm{~g} / \mathrm{d}$ & 1,001 & 1,020 & 1,013 \\
\hline Absorbable $\mathrm{Ca},{ }^{11} \mathrm{~g} / \mathrm{d}$ & 25 & 25 & 44 \\
\hline \multicolumn{4}{|c|}{$\begin{array}{l}{ }^{1} \mathrm{LC}=0.46 \% \mathrm{Ca} \text { and }+167 \mathrm{mEq} / \mathrm{kg} \text { of } \mathrm{DCAD} ; \mathrm{LC}+\mathrm{A}=0.46 \% \mathrm{Ca} \text { and }-13 \mathrm{mEq} / \mathrm{kg} \text { of DCAD; } \mathrm{HC}+\mathrm{A}= \\
0.72 \% \mathrm{Ca} \text { and }-17 \mathrm{mEq} / \mathrm{kg} \text { of DCAD. }\end{array}$} \\
\hline \multicolumn{4}{|c|}{${ }^{2}$ SoyPlus (Landus Cooperative, Ralston, IA). } \\
\hline \multicolumn{4}{|c|}{${ }^{3}$ Dynamate (Mosaic, Lithia, FL). } \\
\hline \multicolumn{4}{|c|}{$\begin{array}{l}{ }^{4} \text { Supplied } 110,000 \mathrm{IU} \text { of vitamin } \mathrm{A}, 35,000 \mathrm{IU} \text { of vitamin } \mathrm{D} \text {, and } 2,500 \mathrm{IU} \text { of vitamin } \mathrm{E} / \mathrm{d} \text { and met or exceeded } \\
\text { NRC (2001) requirements for trace minerals. }\end{array}$} \\
\hline \multirow{2}{*}{\multicolumn{4}{|c|}{$\begin{array}{l}{ }^{5} \text { Dried distillers grains without solubles, rice hulls, and } \mathrm{Mg} \text { oxide (Landus Cooperative). } \\
{ }^{6} \text { Pasturchlor (Landus Cooperative). }\end{array}$}} \\
\hline & & & \\
\hline \multicolumn{4}{|c|}{${ }^{7}$ SoyChlor (Landus Cooperative). } \\
\hline \multicolumn{4}{|c|}{${ }^{8}$ K-Plus (Church \& Dwight, Trenton, NJ). } \\
\hline \multicolumn{4}{|c|}{${ }^{9} \mathrm{DCAD}=(\mathrm{mEq}$ of $\mathrm{Na}+\mathrm{mEq}$ of $\mathrm{K})-(\mathrm{mEq}$ of $\mathrm{Cl}+\mathrm{mEq}$ of $\mathrm{S})}$. \\
\hline \multicolumn{4}{|c|}{${ }^{10}$ Calculated MP based on $12.0 \mathrm{~kg}$ of DMI/d (NRC, 2001). } \\
\hline${ }^{11}$ Calculated absorbable $\mathrm{C}$ & & & \\
\hline
\end{tabular}


$1,25-(\mathrm{OH})_{2} \mathrm{D}$ from the plasma. We could not validate its use in cows without modification. Many animals, including the cow, have vitamin $\mathrm{D}$ binding protein (also known as gc-globulin) that has greater affinity for $1,25-(\mathrm{OH})_{2} \mathrm{D}$ than does human vitamin $\mathrm{D}$ binding protein. The presence of these proteins interferes with the ability of antibodies to bind to $1,25-(\mathrm{OH})_{2} \mathrm{D}$ in bovine plasma. In order for the EIA to work properly, we modified the assay procedure as follows.

The first need was to make EIA bovine standard $1,25-(\mathrm{OH})_{2} \mathrm{D}$ solutions using bovine charcoal stripped plasma. Charcoal can adsorb many steroid molecules within plasma, allowing their removal. Charcoal was prepared by placing $0.75 \mathrm{~g}$ of activated charcoal powder (Fisher Scientific) into a 50-mL plastic tube and adding $30 \mathrm{~mL}$ of a $2.5 \mathrm{mg} / \mathrm{mL}$ dextran T-40 solution (SigmaAldrich, St. Louis, MO). The suspension was incubated at $56^{\circ} \mathrm{C}$ for $30 \mathrm{~min}$ to permit the dextran to bind with the charcoal. The dextran improves precipitation of the charcoal in later steps. The mixture was centrifuged at $3,000 \times g$ for $15 \mathrm{~min}$, and the supernatant was discarded. The charcoal-dextran pellet was washed by adding $45 \mathrm{~mL}$ of distilled water and mixing vigorously. It was centrifuged again, and the supernatant discarded. This washing step was repeated once more. Then, $30 \mathrm{~mL}$ of bovine plasma [obtained from a dry cow 4 wk before calving that was suspected to have low plasma concentrations of $\left.1,25-(\mathrm{OH})_{2} \mathrm{D}\right]$ was added to the charcoal-dextran pellet and mixed well (vortexed). The $\mathrm{pH}$ of this mixture was reduced to $4.0 \mathrm{using} 700 \mu \mathrm{L}$ of $5 \mathrm{M}$ hydrochloric acid added in $25-\mu \mathrm{L}$ increments to liberate $1,25-(\mathrm{OH})_{2} \mathrm{D}$ from vitamin $\mathrm{D}$ binding protein and albumin. The mixture was incubated overnight at $4^{\circ} \mathrm{C}$ with slow mixing to allow the charcoal to bind the $1,25-(\mathrm{OH})_{2} \mathrm{D}$. The mixture was then centrifuged at $3,000 \times g$ for $2 \mathrm{~h}$ at $4^{\circ} \mathrm{C}$. The charcoal-stripped plasma was poured off into a new tube, and the $\mathrm{pH}$ was brought to 7.0. This required using $270 \mu \mathrm{L}$ of $5 \mathrm{M} \mathrm{NaOH}$. The charcoal-stripped plasma was then filtered successively through $0.45-\mu \mathrm{m}$ and $0.20-\mu \mathrm{m}$ filters to remove any charcoal particles that might still be in the plasma. The charcoal-stripped plasma, which had no detectable $1,25-(\mathrm{OH})_{2} \mathrm{D}$, was then used to create bovine standards for the assay by adding $1,000 \mathrm{pg}$ of $1,25-(\mathrm{OH})_{2} \mathrm{D}$ to $4 \mathrm{~mL}$ of charcoal-stripped plasma to create a 250-pg $1,25-(\mathrm{OH})_{2} \mathrm{D} / \mathrm{mL}$ bovine plasma standard. This standard was serially diluted 1:1 with charcoal-stripped plasma to create bovine standards that were $125,62.5$, 31.75 , and $15.87 \mathrm{pg}$ of $1,25-(\mathrm{OH})_{2} \mathrm{D} / \mathrm{mL}$.

These bovine plasma standards (in duplicate) and unknown plasma samples in singlicate $(300 \mu \mathrm{L})$ were delipidated by adding $30 \mu \mathrm{L}$ of a dextran sulfate $-\mathrm{Mg}$ chloride solution (provided with the EIA kit) and centrifuging the sample at $2,000 \times g$ for $15 \mathrm{~min}$. A $200-\mu \mathrm{L}$ aliquot of the delipidated standard or plasma was placed into a $12 \times 75 \mathrm{~mm}$ borosilicate glass tube and mixed with $200 \mu \mathrm{L}$ of acetonitrile to precipitate the plasma proteins and to isolate the $1,25-(\mathrm{OH})_{2} \mathrm{D}$ away from the vitamin $\mathrm{D}$ binding proteins. The plasma-acetonitrile mixture was centrifuged at $2,000 \times g$ for $10 \mathrm{~min}$. A $200-\mu \mathrm{L}$ aliquot of the acetonitrile extract (representing $100 \mu \mathrm{L}$ of plasma or standard solution) was removed and placed into a new $12 \times 75 \mathrm{~mm}$ borosilicate tube and dried to completion under vacuum (Savant Speed Vac concentrator, Thermo Fisher Scientific, Waltham, MA). Each extract was then resuspended in $120 \mu \mathrm{L}$ of PBS that was $5 \%$ glycerin and had $22.5 \mathrm{mg}$ of BSA (Fraction V, Sigma-Aldrich)/mL. A $100-\mu L$ portion of this solution was subjected to immunoextraction using the antibody column provided with the kit, and the $1,25-(\mathrm{OH})_{2} \mathrm{D}$ isolated was subjected to an EIA as prescribed by the manufacturer of the kit from this point on. The assay does not correct for extraction efficiency, but because the standards prepared in charcoal-stripped plasma are subjected to the same extraction procedure as the samples, it is assumed that they will be extracted with similar efficiencies. We estimated $80 \%$ efficiency of extraction in preliminary testing of the modified extraction method. The standard curve generated using human standards supplied by the manufacturer and the standard curve generated using the charcoal-stripped bovine plasma standards ran parallel to each other, demonstrating that the $1,25-(\mathrm{OH})_{2} \mathrm{D}$ originating from bovine plasma standards displaced tracer-labeled $1,25-(\mathrm{OH})_{2} \mathrm{D}$ from the antibody as well as $1,25-(\mathrm{OH})_{2} \mathrm{D}$ originating from human plasma standards (Figure 1). To further validate the assay, we serially diluted plasma from a cow with milk fever that was known to have an elevated concentration of $1,25-(\mathrm{OH})_{2} \mathrm{D}$ with charcoal-stripped plasma and found that the assay detected the serial 2-fold dilution well. A single sample obtained from each cow between 10 and $4 \mathrm{~d}$ before calving was included in a single EIA plate so that interassay variation was eliminated. The manufacturer reported that the intra-assay variation of the EIA with human plasma is 12 to $16 \%$

\section{Statistical Analyses}

For each experiment, data on DMI, plasma $\mathrm{Ca}$, and $\mathrm{Mg}$ concentration were subjected to repeated-measures ANOVA (SAS 8.2, SAS Institute Inc., Cary, NC). Cow nested within dietary treatment was the subject, and day around calving was the repeated measure. The autoregressive covariance structure was used because it yielded the Akaike information criterion that was closest to zero (Littell et al., 1998). The main effects included in the initial model were treatment diet (LC, 


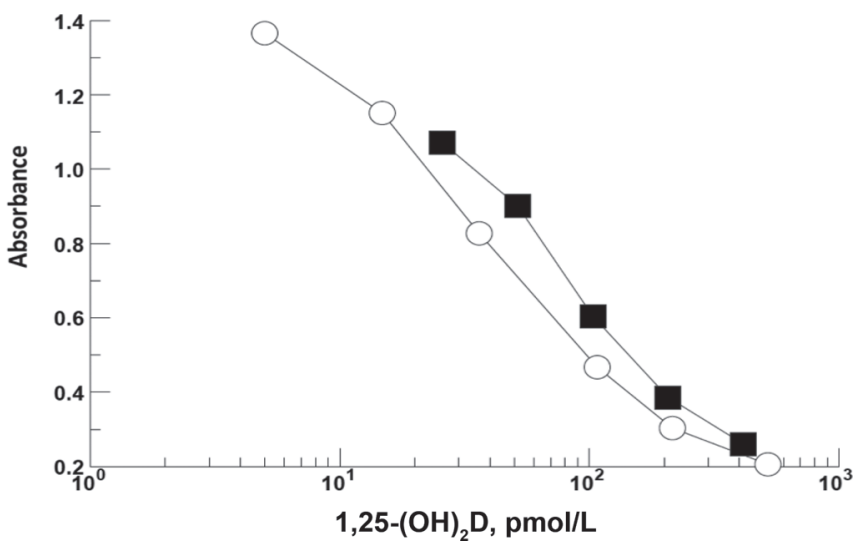

Figure 1. Validation of an enzyme immunoassay modified to determine 1,25 -dihydroxyvitamin $\mathrm{D}\left[1,25-(\mathrm{OH})_{2} \mathrm{D}\right]$ concentrations in bovine plasma. The enzyme immunoassay had a colorimetric readout, with absorbance at a wavelength of $450 \mathrm{~nm}$ depicted on the $\mathrm{y}$ axis. Logarithmic concentrations of $1,25-(\mathrm{OH})_{2} \mathrm{D}$ are presented on the $\mathrm{x}$-axis. Bovine charcoal-stripped plasma with known amounts of $1,25-(\mathrm{OH})_{2} \mathrm{D}$ added $(\boldsymbol{\square})$ was extracted using acetonitrile before immunoextraction and used to generate a standard curve in the enzyme immunoassay. It was found to run parallel to the standards prepared in human plasma $(\bigcirc)$ supplied by the kit manufacturer, which was subjected to the immunoextraction process only as recommended by the manufacturer.

$\mathrm{LC}+\mathrm{A}, \mathrm{HC}+\mathrm{A}$ ), day around calving, and treatment $\times$ day interactions. When ANOVA indicated a significant effect at $P<0.05$, post hoc pairwise testing of differences between least squares means was performed using the Tukey adjustment for the number of tests performed. Data on BCS, urine $\mathrm{pH}$, and plasma PTH and $1,25-(\mathrm{OH})_{2} \mathrm{D}$ (experiment 1 only) concentration before calving were compared by 1-way ANOVA across the 3 treatments in each experiment.

\section{RESULTS}

\section{Experiment 1}

One cow assigned to the $\mathrm{HC}+\mathrm{A}$ group was removed from the study because she delivered a stillborn calf $16 \mathrm{~d}$ before her expected calving date and was not immediately producing milk. The average days on diet before calving were $21.3 \mathrm{~d}$ for the LC group (median: $20 \mathrm{~d}$; shortest time: $13 \mathrm{~d}$ ), $20.2 \mathrm{~d}$ for the LC+A group (median: $19 \mathrm{~d}$; shortest time: $12 \mathrm{~d}$ ), and $19.4 \mathrm{~d}$ for the HC+A group (median: $19 \mathrm{~d}$; shortest time: $13 \mathrm{~d}$ ). The DMI during the period from $14 \mathrm{~d}$ before calving to 3 $\mathrm{d}$ before calving was similar across all 3 treatments at about $13.4 \mathrm{~kg} / \mathrm{d}$ (Figure 2). Based on this intake, the $\mathrm{LC}(\mathrm{n}=20)$ and $\mathrm{LC}+\mathrm{A}(\mathrm{n}=20)$ cows were ingesting $62 \mathrm{~g}$ of $\mathrm{Ca} / \mathrm{d}$, providing about $26 \mathrm{~g}$ of absorbable $\mathrm{Ca}$ (NRC, 2001). Cows in the $\mathrm{HC}+\mathrm{A}(\mathrm{n}=19)$ group were ingesting about $97 \mathrm{~g}$ of $\mathrm{Ca} / \mathrm{d}$, providing about $46 \mathrm{~g}$ of absorbable Ca. Cows in all 3 treatment groups exhibited a decline in feed intake beginning the day before calving and reaching a nadir on the day of calving (d 0 ). On $\mathrm{d} 0$, cows fed the LC diet ate less feed than the cows fed the $\mathrm{LC}+\mathrm{A}$ diet $(P<0.05)$.

Average lactation number the cow was entering, BCS, and urine $\mathrm{pH}$ in the week before calving are presented in Table 3. There were no statistically significant differences in lactation number or BCS across treatments. Mean urine $\mathrm{pH}$ was 8.27 in the $\mathrm{LC}$ cows and was more alkaline $(P<0.05)$ than in the $\mathrm{LC}+\mathrm{A}$ cows $(7.07)$ or the $\mathrm{HC}+\mathrm{A}$ cows (7.41). Cows receiving the $\mathrm{HC}+\mathrm{A}$ diet had numerically higher urine $\mathrm{pH}$ than cows fed the $\mathrm{LC}+\mathrm{A}$ diet, but this difference was not statistically significant $(P=0.16)$.

Plasma Ca concentrations during the periparturient period are presented in Figure 3. There was a significant effect of day around calving, with plasma Ca decreasing in all treatment groups the day of calving. Clinical milk fever (based on cold ears, wobbly gait or recumbency, and plasma Ca less than $5 \mathrm{mg} / \mathrm{dL}$ ) occurred in 3 of 20 cows fed the LC diet, 1 of 19 cows in the $\mathrm{HC}+\mathrm{A}$ diet, and none of the 21 cows fed the $\mathrm{LC}+\mathrm{A}$ diet. All milk fever cases occurred within the first $28 \mathrm{~h}$ after calving. Blood samples were obtained from each of these cows before treatment for milk fever. The cows with milk fever were treated with intravenous $\mathrm{Ca}$ borogluconate; none relapsed, and they remained in the study. On the day of calving (d 0), plasma Ca was significantly lower

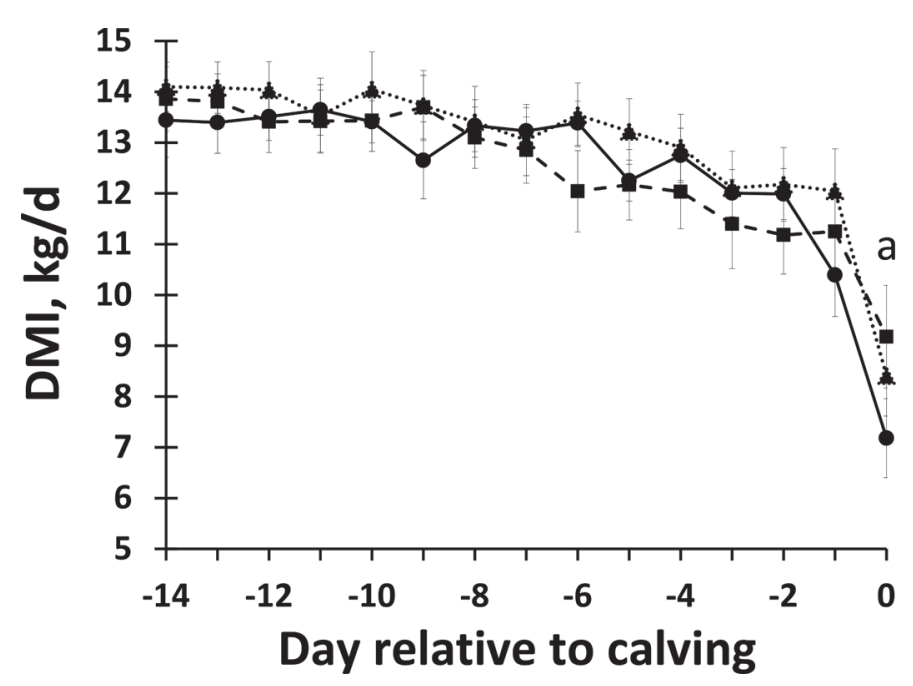

Figure 2. Experiment 1. Dry matter intake $(\mathrm{kg} / \mathrm{d})$ of cows fed $0.46 \% \mathrm{Ca}$ and $+167 \mathrm{mEq} / \mathrm{kg}$ of DCAD (LC; $), 0.46 \% \mathrm{Ca}$ and -13 $\mathrm{mEq} / \mathrm{kg}$ of DCAD (LC+A; - ) or $0.72 \% \mathrm{Ca}$ and $-17 \mathrm{mEq} / \mathrm{kg}$ of DCAD $(\mathrm{HC}+\mathrm{A} ; \boldsymbol{\Delta})$ during the precalving period. Letter (a) denotes significant difference between the LC treatment and the treatments that included supplemental anions on that day. Error bars represent means \pm SEM. 
Table 3. Average lactation number the cow was entering, precalving BCS, precalving urine $\mathrm{pH}$, precalving parathyroid hormone $(\mathrm{PTH})$, and 1,25-dihydroxyvitamin $\mathrm{D}\left[1,25-(\mathrm{OH})_{2} \mathrm{D}\right]$ concentration of cows fed the diets in experiment 1

\begin{tabular}{|c|c|c|c|}
\hline \multirow[b]{2}{*}{ Item } & \multicolumn{3}{|c|}{ Treatment $^{1}$} \\
\hline & $\begin{array}{c}\mathrm{LC} \\
(\mathrm{n}=20)\end{array}$ & $\begin{array}{c}\mathrm{LC}+\mathrm{A} \\
(\mathrm{n}=20)\end{array}$ & $\begin{array}{c}\mathrm{HC}+\mathrm{A} \\
(\mathrm{n}=19)\end{array}$ \\
\hline Lactation no. & $3.76 \pm 0.29$ & $3.65 \pm 0.42$ & $3.37 \pm 0.30$ \\
\hline BCS & $3.71 \pm 0.16$ & $3.45 \pm 0.10$ & $3.60 \pm 0.12$ \\
\hline Urine $\mathrm{pH}$ & $8.27 \pm 0.05$ & $7.07 \pm 0.17^{*}$ & $7.41 \pm 0.17^{*}$ \\
\hline Plasma PTH, ${ }^{2} \mathrm{pg} / \mathrm{mL}$ & $323 \pm 54$ & $398 \pm 70$ & $293 \pm 52$ \\
\hline Plasma $1,25-(\mathrm{OH})_{2} \mathrm{D},{ }^{2} \mathrm{pg} / \mathrm{mL}$ & $87 \pm 7$ & $85 \pm 6$ & $91 \pm 13$ \\
\hline
\end{tabular}

in $\mathrm{LC}$ cows $(7.17 \pm 0.31 \mathrm{mg} / \mathrm{dL})$ than in cows fed the $\mathrm{LC}+\mathrm{A} \operatorname{diet}(7.95 \pm 0.24 \mathrm{mg} / \mathrm{dL} ; P<0.05)$ and the $\mathrm{HC}+\mathrm{A}$ diet $(8.05 \pm 0.27 \mathrm{mg} / \mathrm{dL} ; P<0.04)$. At the 24 $\pm 3 \mathrm{~h}$ blood sampling after calving (d 1$)$, the plasma $\mathrm{Ca}$ of the $\mathrm{LC}$ cows $(7.44 \pm 0.34 \mathrm{mg} / \mathrm{dL})$ remained below that of the $\mathrm{LC}+\mathrm{A}$ cows $(8.09 \pm 0.24 \mathrm{mg} / \mathrm{dL})$ and the $\mathrm{HC}+\mathrm{A}$ cows $(7.98 \pm 0.37)$, but this difference was not statistically significant $(P>0.21)$. Plasma PTH and $1,25-(\mathrm{OH})_{2} \mathrm{D}$ concentrations in a single sample taken between 10 and $4 \mathrm{~d}$ before calving were similar across all treatments (Table 3).

Plasma $\mathrm{Mg}$ concentrations before calving were all more than $2.00 \mathrm{mg} / \mathrm{dL}$ (Figure 4). The day of calving, plasma $\mathrm{Mg}$ concentrations were elevated in all cows and were numerically greatest in the cows fed the LC diet. There was no significant treatment $\times$ day interaction for plasma Mg. The change in plasma Mg concentration

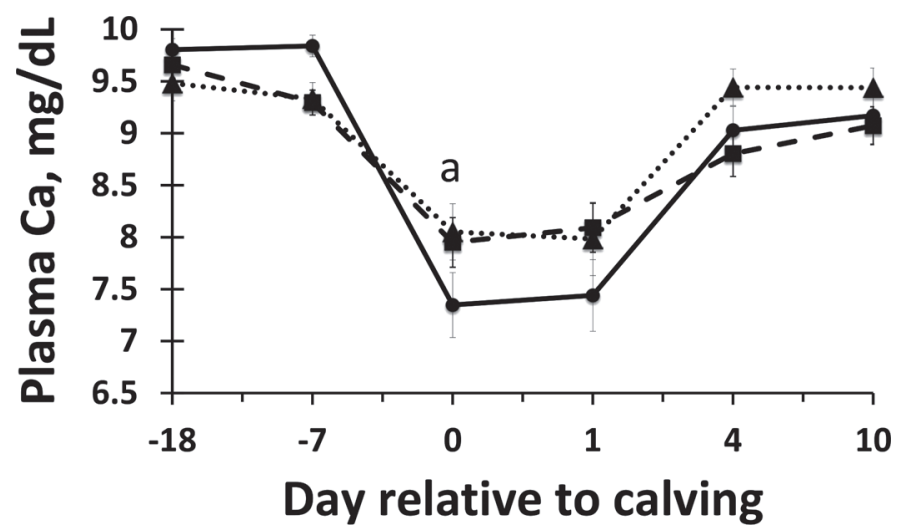

Figure 3. Experiment 1. Plasma $\mathrm{Ca}(\mathrm{mg} / \mathrm{dL})$ concentrations of periparturient cows fed $0.46 \% \mathrm{Ca}$ and $+167 \mathrm{mEq} / \mathrm{kg}$ of DCAD (LC; -), $0.46 \% \mathrm{Ca}$ and $-13 \mathrm{mEq} / \mathrm{kg}$ of DCAD (LC+A; $\mathbf{D})$, or $0.72 \% \mathrm{Ca}$ and $-17 \mathrm{mEq} / \mathrm{kg}$ of $\mathrm{DCAD}(\mathrm{HC}+\mathrm{A} ; \mathbf{\Delta})$ during the precalving period. Letter (a) denotes significant difference between the LC treatment and the treatments that included supplemental anions on that day. Error bars represent means \pm SEM. from $\mathrm{d}-7$ to $\mathrm{d} 0$ was an increase of $0.55 \mathrm{mg} / \mathrm{dL}$ in the $\mathrm{LC}$ cows. This change was greater than the increase of just $0.23 \mathrm{mg} / \mathrm{dL}$ in cows fed the $\mathrm{LC}+\mathrm{A}$ diet $(P=0.04)$. Plasma $\mathrm{Mg}$ concentrations reached their nadir in all treatment groups on d 4 after calving, but all remained above $1.9 \mathrm{mg} / \mathrm{dL}$, which is considered the lower end of the normal range for blood $\mathrm{Mg}$ in cattle.

\section{Experiment 2}

One cow assigned to the high-K $\mathrm{HC}+\mathrm{A}$ diet developed severe Klebsiella mastitis $2 \mathrm{~d}$ before calving, and 1 cow placed on the high-K LC diet developed toxic mastitis at calving. These cows were removed from the study. The average days on diet before calving were $18.1 \mathrm{~d}$ for the high-K LC group (median: $17 \mathrm{~d}$; short-

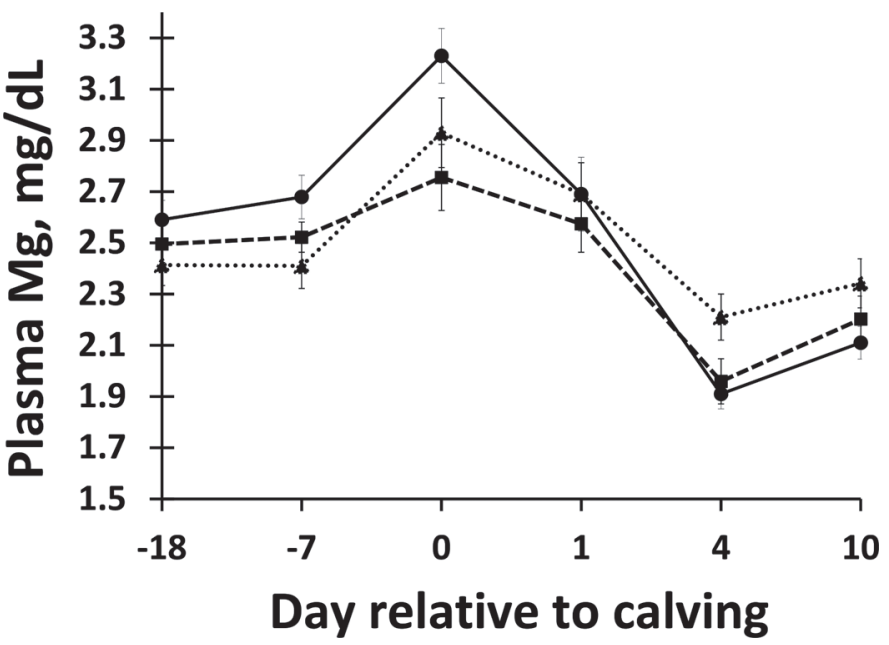

Figure 4. Experiment 1. Plasma $\mathrm{Mg}(\mathrm{mg} / \mathrm{dL})$ concentrations of periparturient cows fed $0.46 \% \mathrm{Ca}$ and $+167 \mathrm{mEq} / \mathrm{kg}$ of DCAD (LC; -), $0.46 \% \mathrm{Ca}$ and $-13 \mathrm{mEq} / \mathrm{kg}$ of DCAD (LC+A; ), or $0.72 \% \mathrm{Ca}$ and $-17 \mathrm{mEq} / \mathrm{kg}$ of $\mathrm{DCAD}(\mathrm{HC}+\mathrm{A} ; \mathbf{\Lambda})$ during the precalving period. Error bars represent means \pm SEM. 
Table 4. Average lactation number cow was entering, precalving BCS, and precalving urine $\mathrm{pH}$ of cows fed the high-K diets in experiment 2

\begin{tabular}{lccc}
\hline & \multicolumn{3}{c}{ Treatment $^{1}$} \\
\cline { 2 - 4 } & $\begin{array}{c}\text { High-K LC } \\
(\mathrm{n}=12)\end{array}$ & $\begin{array}{c}\text { High-K LC+A } \\
(\mathrm{n}=13)\end{array}$ & $\begin{array}{c}\text { High-K HC+A } \\
(\mathrm{n}=12)\end{array}$ \\
Item & $3.25 \pm 0.37$ & $3.00 \pm 0.35$ & $3.00 \pm 0.32$ \\
Lactation no. & $3.67 \pm 0.17$ & $3.63 \pm 0.16$ & $3.95 \pm 0.14$ \\
BCS & $8.51 \pm 0.03$ & $8.26 \pm 0.05^{*}$ & $8.32 \pm 0.04^{*}$ \\
Urine $\mathrm{pH}$ & $346 \pm 99$ & $444 \pm 99$ & $319 \pm 82$ \\
Plasma PTH ${ }^{2} \mathrm{pg} / \mathrm{mL}$ & & \\
${ }^{1} \mathrm{LC}=0.46 \% \mathrm{Ca}$ and $+167 \mathrm{mEq} / \mathrm{kg}$ of $\mathrm{DCAD} ; \mathrm{LC}+\mathrm{A}=0.46 \% \mathrm{Ca}$ and $-13 \mathrm{mEq} / \mathrm{kg}$ of $\mathrm{DCAD} ; \mathrm{HC}+\mathrm{A}=$ \\
$0.72 \% \mathrm{Ca}$ and $-17 \mathrm{mEq} / \mathrm{kg}$ of DCAD. \\
${ }^{2}$ Plasma parathyroid hormone concentrations based on a single sample of blood obtained between 10 and $4 \mathrm{~d}$ \\
before calving. \\
*Significantly different from high-K LC cow values $(P<0.05)$.
\end{tabular}

est time: $12 \mathrm{~d}$ ), $20.0 \mathrm{~d}$ for the high-K LC+A group (median: $19 \mathrm{~d}$; shortest time: $14 \mathrm{~d}$ ), and $20.3 \mathrm{~d}$ for the high-K HC+A group (median: $20 \mathrm{~d}$; shortest time: 12 d). The DMI during the period from $14 \mathrm{~d}$ before calving to $3 \mathrm{~d}$ before calving was not different across all 3 treatments at about $12.0 \mathrm{~kg} / \mathrm{d}$ (Figure 5). Based on this intake, the high-K LC $(\mathrm{n}=12)$ and high-K LC+A $(\mathrm{n}=12)$ cows were ingesting $55 \mathrm{~g}$ of $\mathrm{Ca} / \mathrm{d}$, providing about $25 \mathrm{~g}$ of absorbable $\mathrm{Ca}$ (NRC, 2001). Cows in the high-K HC+A ( $\mathrm{n}=13)$ group were ingesting about $86 \mathrm{~g}$ of $\mathrm{Ca} / \mathrm{d}$, providing about $44 \mathrm{~g}$ of absorbable $\mathrm{Ca}$. Cows in all 3 treatment groups exhibited a slow decline in feed intake the week before calving, reaching a nadir on the day of calving (d 0 ).

Average lactation number the cow was entering, $\mathrm{BCS}$, and urine $\mathrm{pH}$ in the week before calving are presented in Table 4 . There were no statistically significant

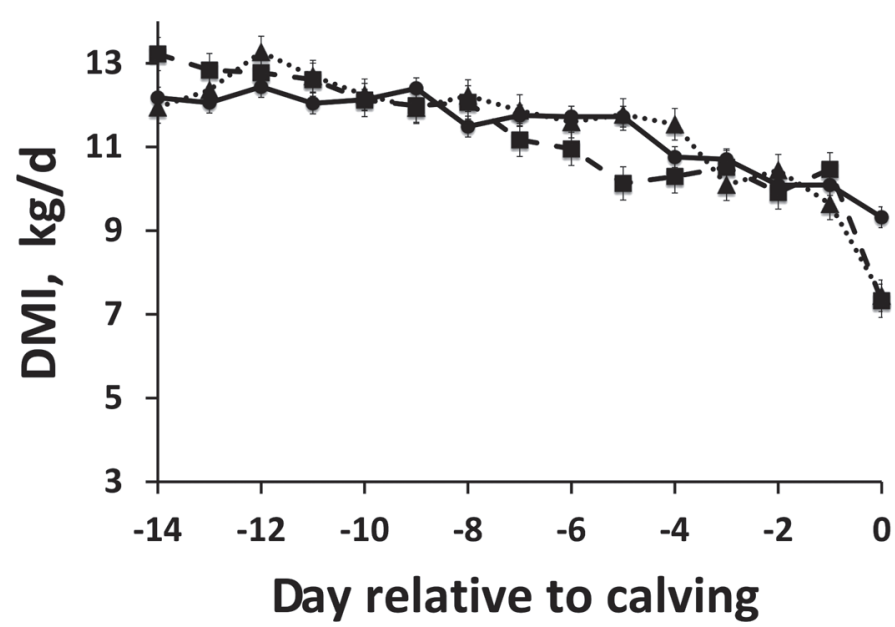

Figure 5. Experiment 2. Dry matter intake $(\mathrm{kg} / \mathrm{d})$ of cows during the $14 \mathrm{~d}$ before calving fed a high-K diet consisting of $0.46 \% \mathrm{Ca}$ and $+167 \mathrm{mEq} / \mathrm{kg}$ of DCAD ( $\mathrm{LC} ; \bullet), 0.46 \% \mathrm{Ca}$ and $-13 \mathrm{mEq} / \mathrm{kg}$ of $\mathrm{DCAD}(\mathrm{LC}+\mathrm{A} ; \mathbf{\square})$, or $0.72 \% \mathrm{Ca}$ and $-17 \mathrm{mEq} / \mathrm{kg}$ of $\mathrm{DCAD}(\mathrm{HC}+\mathrm{A}$; $\Delta$ ) during the precalving period. Error bars represent means \pm SEM. differences in lactation number or BCS across treatments. Mean urine $\mathrm{pH}$ was 8.51 in the high-K LC cows and was more alkaline than in the high-K LC+A cows (8.26) or the high-K $\mathrm{HC}+\mathrm{A}$ cows $(8.32 ; P<0.05)$. Cows receiving the high- $\mathrm{K} \mathrm{HC}+\mathrm{A}$ diet had numerically higher urine $\mathrm{pH}$ than cows fed the high-K LC+A diet, but this difference was not statistically significant $(P$ $=0.36)$.

Plasma Ca concentrations during the periparturient period are presented in Figure 6. There was a significant effect of day around calving, with plasma Ca decreasing in all treatment groups the day of calving. There was no significant treatment $\times$ day interaction for plasma $\mathrm{Ca}$ concentration. Clinical milk fever (based on cold ears, wobbly gait or recumbency, and plasma Ca less than $5 \mathrm{mg} / \mathrm{dL}$ ) occurred in 1 of 12 cows fed the high-K LC diet, 3 of 13 cows fed the high-K HC+A diet, and 1 of 12 cows fed the high-K LC+A diet. All milk fever cases occurred in the first $24 \mathrm{~h}$ after calving. Blood samples were obtained from each of these cows before treatment for milk fever. About $24 \mathrm{~h}$ after being treated for milk fever, 1 cow in the high-K LC group and 2 cows in the high-K HC+A group were given an oral $\mathrm{Ca}$ gel containing $53 \mathrm{~g}$ of $\mathrm{Ca}$, primarily as Ca chloride (Cal-gel, Jorgensen Labs, Loveland, CO) as the farm veterinarian thought the cows were hypocalcemic. Blood samples were obtained before these treatments were given. The data from these cows remained in the data set. Plasma Ca concentration reached a nadir at $12 \pm 4 \mathrm{~h}(0.5 \mathrm{~d})$ in the high-K LC $(7.5 \mathrm{mg} / \mathrm{dL})$ and high-K LC+A $(7.2$ $\mathrm{mg} / \mathrm{dL}$ ) groups and at $24 \pm 4 \mathrm{~h}$ (d 1) for the high-K $\mathrm{HC}+\mathrm{A}(7.13 \mathrm{mg} / \mathrm{dL})$ group. There were no significant differences in plasma $\mathrm{Ca}$ across the treatment groups before or after calving. Plasma PTH concentrations in a blood sample taken between 10 and $4 \mathrm{~d}$ before calving were also not different across all treatments (Table 4).

Plasma $\mathrm{Mg}$ concentrations before calving were all more than $2.00 \mathrm{mg} / \mathrm{dL}$ (Figure 7 ). The day of calv- 


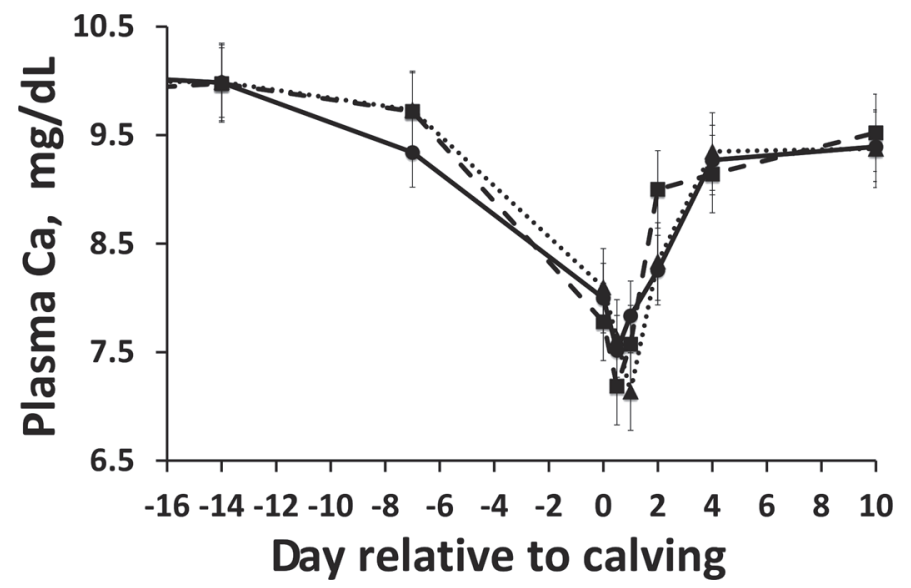

Figure 6. Experiment 2. Plasma Ca concentrations $(\mathrm{mg} / \mathrm{dL})$ of periparturient cows fed a high- $\mathrm{K}$ diet consisting of $0.46 \% \mathrm{Ca}$ and +167 $\mathrm{mEq} / \mathrm{kg}$ of DCAD (LC; $\bullet), 0.46 \% \mathrm{Ca}$ and $-13 \mathrm{mEq} / \mathrm{kg}$ of DCAD $(\mathrm{LC}+\mathrm{A} ; \boldsymbol{\square})$, or $0.72 \% \mathrm{Ca}$ and $-17 \mathrm{mEq} / \mathrm{kg}$ of $\mathrm{DCAD}(\mathrm{HC}+\mathrm{A} ; \mathbf{\Delta})$ during the precalving period. Error bars represent means \pm SEM.

ing plasma $\mathrm{Mg}$ concentrations were elevated similarly in all cows. There was no significant treatment $\times$ day interaction for plasma $\mathrm{Mg}$ concentration. Plasma $\mathrm{Mg}$ concentrations reached their nadir in all treatment groups on $\mathrm{d} 4$ after calving but remained greater than $1.8 \mathrm{mg} / \mathrm{dL}$.

\section{DISCUSSION}

One way to reduce the degree of hypocalcemia experienced by the periparturient dairy cow is to place the cow in negative Ca balance for 10 to $14 \mathrm{~d}$ before calving (Goings et al., 1974; Green et al., 1981). In both experiments 1 and 2, the $\mathrm{LC}$ diet $\mathrm{Ca}$ concentrations were about $0.46 \% \mathrm{Ca}$, with much of that $\mathrm{Ca}$ coming from forages. The NRC (2001) model predicted that these diets, consumed in the amounts observed in these 2 experiments, supplied a minimum of $25 \mathrm{~g}$ of absorbable $\mathrm{Ca} / \mathrm{d}$. These diets would, according to that model, supply at least $8 \mathrm{~g}$ more absorbed $\mathrm{Ca} / \mathrm{d}$ than the cows needed to meet their Ca needs. Studies that successfully used the low-Ca diet strategy to prevent hypocalcemia were able to place the cow in negative Ca balance. This caused an increase in blood PTH concentration within 3 to $4 \mathrm{~d}$ of the cow being placed on the low-Ca diet (Goings et al., 1974; Green et al., 1981; Kichura et al., 1982). In our study, the LC diet was unable to cause a significant increase in PTH concentration in either experiment over the $\mathrm{HC}+\mathrm{A}$ diet before calving.

The PTH secreted in response to hypocalcemia at calving raises the renal threshold for reabsorption of $\mathrm{Mg}$ by the renal tubules, thus increasing plasma $\mathrm{Mg}$ concentrations (Goff, 2014). Plasma $\mathrm{Mg}$ increases at calving in most dairy cows that are on a diet sufficient in $\mathrm{Mg}$ because most cows experience some degree of hypocalcemia at the onset of lactation. The cows in all treatment groups were receiving an ample supply of diet $\mathrm{Mg}$ precalving. The greater increase in plasma $\mathrm{Mg}$ from around $7 \mathrm{~d}$ before calving to calving in the $\mathrm{LC}$ cows in experiment 1 adds further evidence that they were more hypocalcemic than the $\mathrm{LC}+\mathrm{A}$ cows. Plasma $\mathrm{Mg}$ concentrations were lower after calving than before calving, though still in the normal range. This may reflect the fact that all supplemental $\mathrm{Mg}$ in the lactation diet came from $\mathrm{Mg}$ oxide, which can be quite variable in its availability.

Anionic salts acidify the cow's urine and make renal tubular reabsorption of $\mathrm{Ca}$ filtered across the renal glomerulus less efficient. As a result, urine Ca content increases by 4 to $7 \mathrm{~g} / \mathrm{d}$ in cows that have urine $\mathrm{pH}$ below 6.0 (Schonewille et al., 1999; Goff et al., 2014). We did not determine Ca loss in the urine in this study. However, the addition of anions to the $0.46 \% \mathrm{Ca}$ diet did not seem to cause enough Ca loss through the urine to place the cow in negative $\mathrm{Ca}$ balance because the PTH and 1,25- $(\mathrm{OH})_{2} \mathrm{D}$ concentrations in the cows fed the high-Ca diets with anions were not different at $7 \pm$ $3 \mathrm{~d}$ before calving. It is also important to consider that in this study we did not add enough anions to induce a highly acidic urine $\mathrm{pH}$ in the cows, and urine Ca loss does not increase appreciably in cows until urine $\mathrm{pH}$ decreases below about 6.8 (Gelfert et al., 2007). Perhaps cows with urine $\mathrm{pH}$ of 5.5 to 6.0 , coupled with a low-Ca diet, would have been losing enough $\mathrm{Ca}$ in the urine to

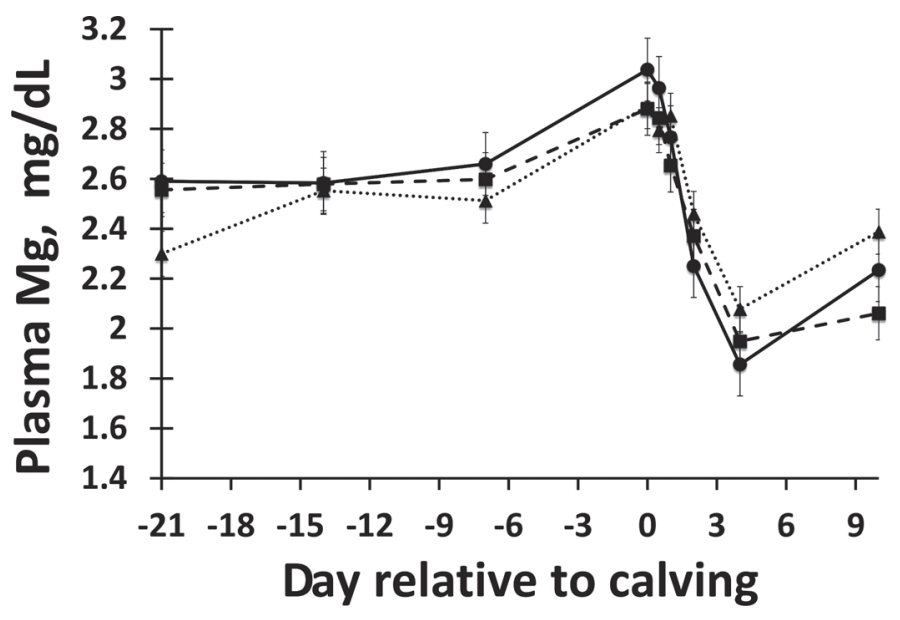

Figure 7. Experiment 2. Plasma $\mathrm{Mg}$ concentrations $(\mathrm{mg} / \mathrm{dL})$ of periparturient cows fed a high-K diet consisting of $0.46 \% \mathrm{Ca}$ and +167 $\mathrm{mEq} / \mathrm{kg}$ of DCAD (LC; $\bullet$ ), $0.46 \% \mathrm{Ca}$ and $-13 \mathrm{mEq} / \mathrm{kg}$ of DCAD $(\mathrm{LC}+\mathrm{A} ; \boldsymbol{\square})$, or $0.72 \% \mathrm{Ca}$ and $-17 \mathrm{mEq} / \mathrm{kg}$ of $\mathrm{DCAD}(\mathrm{HC}+\mathrm{A} ; \mathbf{\Lambda})$ during the precalving period. Error bars represent means \pm SEM. 
place them into negative Ca balance. That experiment remains to be done.

A practical question in dry cow nutrition revolves around the amount of $\mathrm{Ca}$ that should be fed when using the strategy of feeding anions to reduce hypocalcemia. Meta-analyses of the literature on milk fever and diet suggest that the incidence of milk fever peaks when diet Ca is 1.2 to 1.4\% (Oetzel, 1991; Lean et al., 2006) and is greatly reduced when diet $\mathrm{Ca}$ is less than $0.7 \%$ or greater than $1.7 \%$. In experiment 1 of our study, no disadvantage was observed in periparturient plasma Ca concentration when increasing anionic diet Ca from $0.46 \%$ to $0.72 \%$. In a previous study, we observed that cows fed more highly anionic diets that were 0.52 or $1.32 \%$ Ca had similar blood Ca concentration during the periparturient period (Goff and Horst, 1997). Our studies suggest that there are no benefits and no disadvantages to adding $\mathrm{Ca}$ to anionic diets when diet $\mathrm{Ca}$ is between 0.5 and $1.3 \%$. Beede et al. (2001) found no significant difference in blood Ca concentration in cows fed anionic diets that ranged from 0.47 to $1.95 \% \mathrm{Ca}$. However, DMI decreased as diet Ca increased above $1.5 \%$.

Lactating cow diets are often less than $1 \% \mathrm{Ca}$ and will meet the cow's Ca demands for lactation (NRC, 2001). The rationale for feeding diets with more than $1 \%$ Ca to dry cows, who have relatively low Ca requirements, and then reducing the diet Ca below $1 \%$ as the cow begins lactation is unclear. Perhaps it is possible for the higher Ca diet to create a depot of unabsorbed Ca within the lumen of the intestinal tract that can then be absorbed once the active transport of $\mathrm{Ca}$ across the intestinal cells has been stimulated by $1,25-(\mathrm{OH})_{2} \mathrm{D}$. Although the debate may continue over the desired dietary Ca for close-up dry cows, it is clear from our study and that of Schonewille et al. (1994) that when the Ca content of the diet increases, the urine $\mathrm{pH}$ will be slightly higher than when $\mathrm{Ca}$ is not added to the diet. More anion needs to be added to the higher Ca diet to achieve the same degree of urine and blood acidification. This is consistent with observations of Goff et al. (2004) suggesting that diet $\mathrm{Ca}$, ammonium, and $\mathrm{Mg}$ cations are slightly alkalinizing to blood and urine. To date, no studies have experimentally tested and supported the meta-analyses suggestion that anionic diets need to be below $0.7 \% \mathrm{Ca}$ or above $1.4 \% \mathrm{Ca}$ to be most effective.

Another meta-analysis suggested that lowering the DCAD is strongly associated with improved $\mathrm{Ca}$ status at calving (Charbonneau et al., 2006). Reducing urine pH below 7 (Charbonneau et al., 2006; Kurosaki et al., 2007) or more commonly below 6.5 (Jardon, 1995; Goff, 2014) induces a mild compensated metabolic acidosis, permitting more effective Ca homeostasis. In most cases, diet DCAD, defined as $(\mathrm{mEq}$ of $\mathrm{Na}+\mathrm{mEq}$ of
$\mathrm{K})-(\mathrm{mEq}$ of $\mathrm{Cl}+\mathrm{mEq}$ of $\mathrm{S})$, will be less than -50 $\mathrm{mEq} / \mathrm{kg}$ to achieve urine $\mathrm{pH}$ below 7.0 (Charbonneau et al., 2006).

Moore et al. (2000) fed diets with DCAD [(Na $+\mathrm{K})$ $-(\mathrm{Cl}+\mathrm{S})]$ of +150 (basal diet with no anion added), 0 , and $-150 \mathrm{mEq} / \mathrm{kg}$ of DM. They found that blood Ca concentration at calving increased with each decrease in diet DCAD. Average urine $\mathrm{pH}$ went from 7.95 to 7.32 and 6.01 as DCAD decreased. This study would seem to have proven that partial acidification was better than no acidification and that full acidification was better than partial acidification. However, critics of this study point out that diet $\mathrm{Ca}$ also increased as DCAD decreased because $\mathrm{Ca}$ chloride and $\mathrm{Ca}$ sulfate were major anion sources utilized. Another criticism is that diet $\mathrm{Mg}$ was just $0.20 \%$ in the highest DCAD diets and increased to $0.28 \%$ in the low-DCAD diet because $\mathrm{Mg}$ sulfate was also used in the anion supplement. Although blood $\mathrm{Mg}$ concentration was not reported in that study, low diet $\mathrm{Mg}$ is also known to contribute greatly to hypocalcemia in cows, so it may be argued that the effectiveness of their low-DCAD diet was partially due to better Mg status (Lean et al., 2006; Goff, 2014).

Liesegang et al. (2007) fed 0.4 or $0.8 \%$ Ca diets with and without anions. They also determined that $0.4 \%$ $\mathrm{Ca}$ without anions was unable to promote $\mathrm{Ca}$ homeostatic mechanisms that would reduce hypocalcemia at calving. Unfortunately, the amount of anion added to these diets was able to reduce urine $\mathrm{pH}$ in only the $0.4 \% \mathrm{Ca}$ with anions group. With just 6 animals in each treatment, they could not detect a difference in blood Ca concentration across the different diets.

Joyce et al. (1997) added anions to an alfalfa-based precalving ration and found a benefit to plasma $\mathrm{Ca}$ around the time of calving despite reducing the urine $\mathrm{pH}$ to just 7.3 the day before calving. Control (no anion) cows had urine $\mathrm{pH}$ above 8.0. The calculated DCAD of the control diet was $+350 \mathrm{mEq} / \mathrm{kg}$, and that of the anionic diet was $-70 \mathrm{mEq} / \mathrm{kg}$. Our data suggest that diets with DCAD close to $0 \mathrm{mEq} / \mathrm{kg}$, which succeeded in reducing urine $\mathrm{pH}$ to just 7.1 or 7.4 , benefitted plasma Ca more than a diet with no added anions. Adding a similar amount of anions to a diet that was higher in potassium (experiment 2) reduced urine $\mathrm{pH}$ from 8.51 to 8.26 but was unable to improve plasma $\mathrm{Ca}$ at calving. The DCAD of these diets remained above $140 \mathrm{mEq} / \mathrm{kg}$. Anion addition to diets must take into account the amount of cations in the diet; 1 dose of anions does not suit all diets. Because metabolic alkalosis was not effectively reduced in experiment 2 , the PTH sensitivity of the tissues of the cows remained impaired and there was no improvement in periparturient blood Ca concentrations (Goff et al., 2014). 


\section{CONCLUSIONS}

Typically, anions are added to diets to acidify the cow to improve Ca homeostasis. Most studies suggest that optimal or full acidification of the cow will be accompanied by urine $\mathrm{pH}$ below 7.0, and some studies in the literature support full acidification of cows as the preferred method for reducing hypocalcemia (Moore et al., 2000). In experiment 1, a lower inclusion rate of anions caused partial acidification of the cows. Reducing urine $\mathrm{pH}$ below 7.5 significantly improved periparturient Ca plasma concentration. However, in experiment 2 , when a similar amount of anions was added to a higher $\mathrm{K}$ diet and the urine $\mathrm{pH}$ remained above 8.0, there was no improvement in plasma $\mathrm{Ca}$ concentration over the diet without added anions. Urine $\mathrm{pH}$ testing is the simplest and least expensive way to detect the effect of the diet on the cow's acid-base status. In both experiments, cows fed the $0.46 \% \mathrm{Ca}$ precalving diet without anions had the lowest periparturient plasma $\mathrm{Ca}$ concentrations. There was no evidence that $0.46 \%$ $\mathrm{Ca}$ concentration was low enough to stimulate PTH secretion and upregulate $\mathrm{Ca}$ homeostatic mechanisms before calving to prevent hypocalcemia. Cows fed anionic diets that succeeded in reducing urine $\mathrm{pH}$ had similar periparturient $\mathrm{Ca}$ concentrations whether the diet was 0.46 or $0.72 \% \mathrm{Ca}$. Cows fed higher $\mathrm{Ca}$ anion diets had numerically higher urine $\mathrm{pH}$, suggesting that a higher anion inclusion rate would be needed to overcome the alkalinizing effect of diet $\mathrm{Ca}$ if achieving a similar degree of acidification is desired.

\section{ACKNOWLEDGMENTS}

This study would not have been possible without the technical help of Ed Zaworski, who did the bulk of the feeding and blood sampling of the cows. He was aided greatly by Iowa State University veterinary students Chad Clancy, Julia Gloviczky, Meghan Fick, Paige Linden, and Amanda Stout. Iowa State University research associate Cathy Martens was vital to the blood analyses. The authors thank Joe Dietrich and the staff of the Iowa State Dairy Farm for use of the cows in this study as well as Landus Cooperative (Ralston, IA) for providing the dietary treatment supplements used in these studies and for providing monetary support that allowed Goff to hire veterinary students to conduct these studies. We also thank Immunodiagnostic Systems (Boldon, UK) for donating the enzyme immunoassay kits that allowed us to develop an adaptation of the kit to assess bovine blood 1,25-dihydroxyvitamin D concentrations. Goff was formerly the director of research for the West Central Farmer's Cooperative, currently Landus Cooperative. He helped develop both SoyChlor and PasturChlor while working at the cooperative. He continues to work as a consultant for Landus Cooperative.

\section{REFERENCES}

Beede, D. K., T. E. Pilbeam, S. M. Puffenbarger, and R. J. Tempelman. 2001. Peripartum responses of Holstein cows and heifers fed graded concentrations of calcium (calcium carbonate) and anion (chloride) three weeks before calving. J. Dairy Sci. 84:83. (Abstr.)

Beede, D. K., C. Wang, G. A. Donovan, L. F. Archibald, and W. K. Sanchez. 1991. Dietary cation-anion difference (electrolyte balance) in late pregnancy. Pages 98-104 in Proc. Florida Dairy Prod. Conf., Gainesville. University of Florida, Gainesville.

Block, E. 1984. Manipulating dietary anions and cations for prepartum dairy cows to reduce incidence of milk fever. J. Dairy Sci. 67:2939-2948.

Boda, J. M., and H. H. Cole. 1954. The influence of dietary calcium and phosphorus on the incidence of milk fever. J. Dairy Sci $37: 360-372$.

Charbonneau, E., D. Pellerin, and G. R. Oetzel. 2006. Impact of lowering dietary cation-anion difference in nonlactating dairy cows: A meta-analysis. J. Dairy Sci. 89:537-548.

Dishington, I. W. 1975. Prevention of milk fever (hypocalcemic paresis puerperalis) by dietary salt supplements. Acta Vet. Scand $16: 503-512$

Ender, F., I. W. Dishington, and A. Helgebostad. 1971. Calcium balance studies in dairy cows under experimental induction and prevention of hypocalcaemic paresis puerperalis. The solution of the aetiology and the prevention of milk fever by dietary means. Z . Tierphysiol. 28:233-256.

Ferguson, J. D., D. T. Galligan, and N. Thomsen. 1994. Principal descriptors of body condition score in Holstein cows. J. Dairy Sci. 77:2695-2703.

Gaynor, P. J., F. J. Mueller, J. K. Miller, N. Ramsey, J. P. Goff, and R. L. Horst. 1989. Parturient hypocalcemia in Jersey cows fed alfalfa havlage-based diets with different cation to anion ratios. J. Dairy Sci. 72:2525-2531.

Gelfert, C. C., S. Leonie Loeffler, S. Frömer, M. Engel, H. Hartmann, K. Männer, W. Baumgartner, and R. Staufenbiel. 2007. The impact of dietary cation anion difference (DCAD) on the acid-base balance and calcium metabolism of non-lactating, non-pregnant dairy cows fed equal amounts of different anionic salts. J. Dairy Res. 74:311-322.

Goff, J. P. 2014. Calcium and magnesium disorders. Vet. Clin. North Am. Food Anim. Pract. 30:359-381.

Goff, J. P., and R. L. Horst. 1997. Effects of the addition of potassium or sodium, but not calcium, to prepartum rations on milk fever in dairy cows. J. Dairy Sci. 80:176-186.

Goff, J. P., A. Liesegang, and R. L. Horst. 2014. Diet-induced pseudohypoparathyroidism: A hypocalcemia and milk fever risk factor. J. Dairy Sci. 97:1520-1528.

Goff, J. P., E. T. Littledike, and R. L. Horst. 1986. Effect of synthetic bovine parathyroid hormone in dairy cows: Prevention of hypocalcemic parturient paresis. J. Dairy Sci. 69:2278-2289.

Goff, J. P., R. Ruiz, and R. L. Horst. 2004. Relative acidifying activity of anionic salts commonly used to prevent milk fever. J. Dairy Sci $87: 1245-1255$

Goings, R. L., N. L. Jacobson, D. C. Beitz, E. T. Littledike, and K. D Wiggers. 1974. Prevention of parturient paresis by a prepartum, calcium-deficient diet. J. Dairy Sci. 57:1184-1188.

Green, H. B., R. L. Horst, D. C. Beitz, and E. T. Littledike. 1981. Vitamin D metabolites in plasma of cows fed a prepartum lowcalcium diet for prevention of parturient hypocalcemia. J. Dairy Sci. 64:217-226.

Jardon, P. W. 1995. Using urine $\mathrm{pH}$ to monitor anionic salt programs, Compend. Contin. Educ. Pract. Vet. 17:860-862.

Joyce, P. W., W. K. Sanchez, and J. P. Goff. 1997. Effect of anionic salts in prepartum diets based on alfalfa. J. Dairy Sci. 80:28662875 . 
Kichura, T. S., R. L. Horst, D. C. Beitz, and E. T. Littledike. 1982. Relationships between prepartal dietary calcium and phosphorus, vitamin D metabolism, and parturient paresis in dairy cows. J. Nutr. 112:480-487.

Kurosaki, N., O. Yamato, F. Mori, S. Imoto, and Y. Maede. 2007. Preventive effect of mildly altering dietary cation-anion difference on milk fever in dairy cows. J. Vet. Med. Sci. 69:185-192.

Lean, I. J., P. J. DeGaris, D. M. McNeil, and E. Block. 2006. Hypocalcemia in dairy cows: Meta-analysis and dietary cation anion difference theory revisited. J. Dairy Sci. 89:669-684.

Liesegang, A., C. Chiappi, J. Risteli, J. Kessler, and H. D. Hess. 2007. Influence of different calcium contents in diets supplemented with anionic salts on bone metabolism in periparturient dairy cows. J. Anim. Physiol. Anim. Nutr. (Berl.) 91:120-129.

Liesegang, A., M. L. Sassi, J. Risteli, R. Eicher, M. Wanner, and J. L. Riond. 1998. Comparison of bone resorption markers during hypocalcemia in dairy cows. J. Dairy Sci. 81:2614-2622.

Littell, R. C., P. R. Henry, and C. B. Ammerman. 1998. Statistical analysis of repeated measures data using SAS procedures. J. Anim. Sci. 76:1216-1231.

Moore, S. J., M. J. VandeHaar, B. K. Sharma, T. E. Pilbeam, D. K. Beede, H. F. Bucholtz, J. S. Liesman, R. L. Horst, and J. P.
Goff. 2000. Effects of altering dietary cation-anion difference on calcium and energy metabolism in peripartum cows. J. Dairy Sci. 83:2095-2104.

National Research Council. 2001. Nutrient Requirements of Dairy Cattle. 7th rev. ed. Natl. Acad. Press, Washington, DC.

Oetzel, G. R. 1991. Meta-analysis of nutritional risk factors for milk fever in dairy cattle. J. Dairy Sci. 74:3900-3912.

Oetzel, G. R., J. D. Olson, C. R. Curtis, and M. J. Fettman. 1988. Ammonium chloride and ammonium sulfate for prevention of parturient paresis in dairy cows. J. Dairy Sci. 71:3302-3309.

Schonewille, J. T., A. T. Van't Klooster, A. Dirkzwager, and A. C. Beynen. 1994. Stimulatory effect of an anion(chloride)-rich ration on apparent calcium absorption in dairy cows. Livest. Prod. Sci. 40:233-240

Schonewille, J. T., A. T. Van't Klooster, H. Wouterse, and A. C. Beynen. 1999. Hypocalcemia induced by intravenous administration of disodium ethylenediaminotetraacetate and its effects on excretion of calcium in urine of cows fed a high chloride diet. J. Dairy Sci. 82:1317-1324. 